\title{
Protective effect of Nigella sativa on sperm parameters in mice exposed to titanium dioxide during embryonic development
}

\author{
Abouzaripour $\mathrm{M}^{1}$, Hosaini Bae $\mathrm{M}^{2}$, Rezaie $\mathrm{MJ}^{3}$, Nikkho $\mathrm{B}^{4}$, Allahveisi $\mathrm{A}^{5}$, Roshani $\mathrm{D}^{6}$, Khalesro $\mathrm{SH}^{7}$, \\ Daneshi $\mathbf{E}^{8}$ \\ 1. Assistant Professor, Cellular and Molecular Research Center, Research Institute for Health Development, Kurdistan \\ University of Medical Sciences, Sanandaj, Iran. \\ 2. Msc Student of Anatomical Sciences, Cellular and Molecular Research Center, Research Institute for Health Development, \\ Kurdistan University of Medical Sciences, Sanandaj, Iran. \\ 3. Associate Professor, Infertility Treatment Center, Besat Hospital, Kurdistan University of Medical Sciences, Sanandaj, \\ Iran. \\ 4. Associate professor, Department of Pathology, School of Medicine, Kurdistan University of Medical Sciences, Sanandaj, \\ Iran \\ 5. Assistant Professor, Infertility Treatment Center, Besat Hospital, Kurdistan University of Medical Sciences, Sanandaj, \\ Iran. \\ 6. Associate Professor, Social Determinants of Health Research Center, Research Institute for Health Development, \\ Kurdistan University of Medical Sciences, Sanandaj, Iran. \\ 7. Assistant Professor, Department of Agronomy and Plant Breeding, Faculty of Agriculture, University of Kurdistan, \\ Sanandaj, Iran. \\ 8. Assistant Professor, Cellular and Molecular Research Center, Research Institute for Health Development, Kurdistan \\ University of Medical Sciences, Sanandaj, Iran (Corresponding Author), Tel: +98-8733664658, Email: \\ erfan.daneshi@yahoo.com
}

\begin{abstract}
Background and Aim: Nanotechnology is the precise and controlled manipulation of the atomic or molecular structure of nanoscale materials for the preparation of particulate matter with new properties and specific applications. Many in vivo and in vitro studies have shown the negative and destructive effects of nanoparticles on male germ cells.Nanoparticles include primary particles with at least one of their dimensions less than $100 \mathrm{~nm}$.
\end{abstract}

Material and Method: This study included 20 male and female adult mice (NMRI), between 6 and 8 weeks of age and weight of 25-30 g. We placed every two adult female mice with a male adult mouse in a cage for mating. Pregnant mice were randomly divided into 4 groups.(control,titanium, nigella sativa,titanium +nigella sativa). Animals were sacrificed by cervical spine dislocation under anesthesia. Then, using a neobar lamel and under the optical microscope, number of sperms and their morphology were assessed.

Result : In this study, semen parameters including sperm morphology and number and also weights of organs were assessed. We found decreased number of sperms, increased number of abnormal sperms and decreased weight in the titanium group. But protective effect of Nigella sativa in the treatment group led to a significant difference in the sperm parameters compared to that in the titanium group $(\mathrm{p}<0.05)$.

Conclusion: TNP reduced sperm count and increased the number of abnormal sperms, Previous studies by Hajshafiha showed the ability of nanoparticles to cross the bloodtesticular barrier. Protective and antioxidant effects of Nigella sativa can greatly reduce the toxicity of TNP. NS had a potent protective effect against the toxic effect of TNP on testese.

Keyword: Titanium nanoparticle, Nigella sativa, Parameter

Received: Oct 16, 2018

Accepted: Feb 17, 2019

How to cite the article: Abouzaripour M, Hosaini Bae M, Rezaie MJ, Nikkho B, Allahveisi A, Roshani D, Khalesro SH, Daneshi E. Protective effect of Nigella sativa on sperm parameters in mice exposed to titanium dioxide during embryonic development. SJKU 2019;24(2):66-73. 


\section{بررسى اثر محافظتى سياه دانه بر هار امتر هاى اسبرم در موشهاى دريافت كننده نانوذره اكسيد تيتانيوم در زمان تكامل جنان}

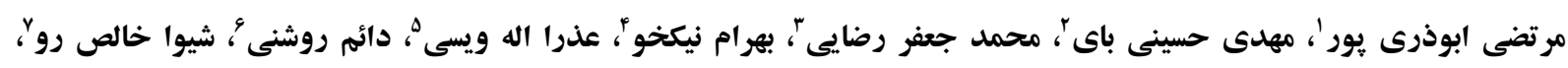

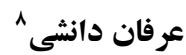

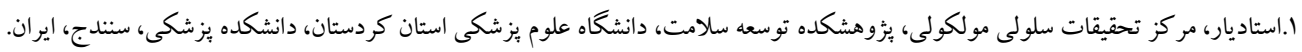

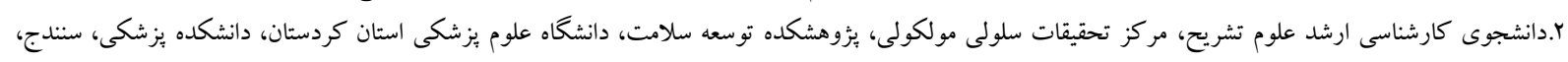

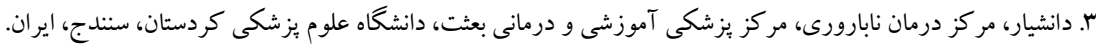

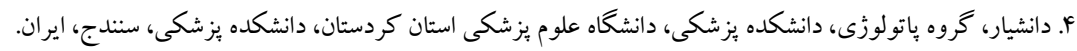

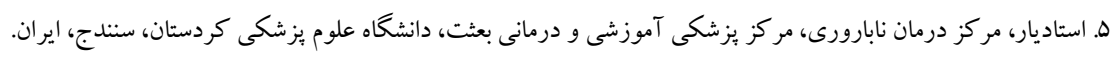

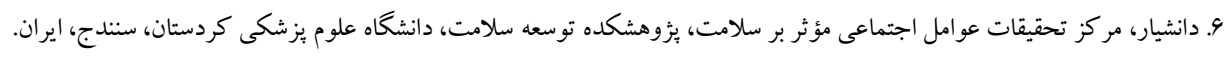

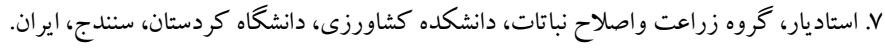

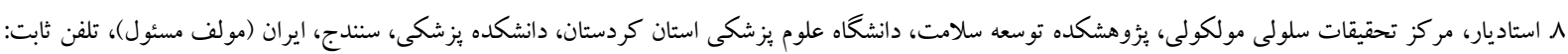

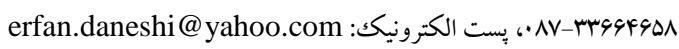

\section{جكيده}

زمينه و هدف: نانو تكنولوزى عبارت است از دست كارى دقيق و كنترلشده ساختار اتمى يا مولكولى مواد در مقياس نانو بهمنظور تهيه ريز ذراتى با خصوصيات نوظهور و كاربردهاى خاص. بسيارى از مطالعات in vivo و

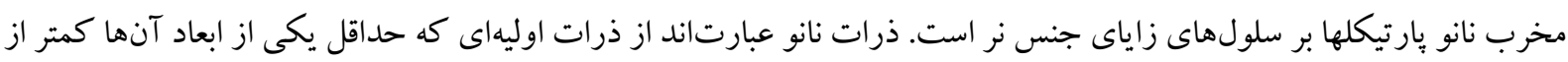

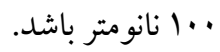

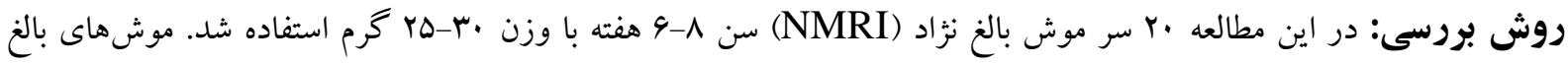

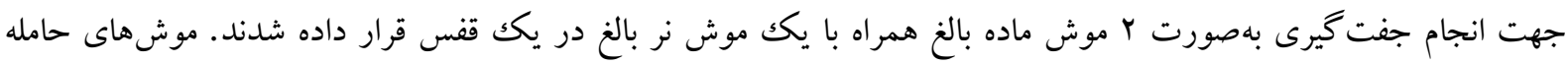

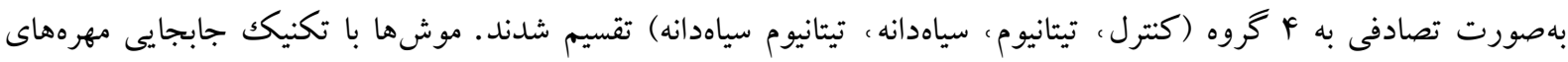

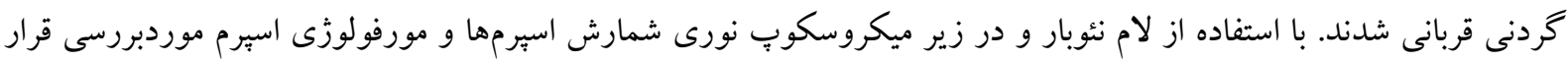
مى گيرد. يافته ها: در اين بررسى بارامترهاى سيمن ازنظر تعداد اسبرم و مورفولوزى اسبرم و وزن ار گانها مورد مطالعه قراركرفتند. كاهش

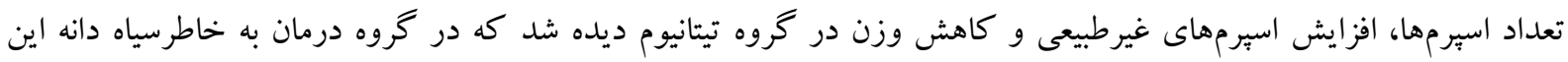
تغييرات جبران شدند (ه • P ( P ). يافته ها: نانوذره اكسيد تيتانيوم مىتواند باعث كاهش شمارش اسيرم و افزايش اسبرمهاى غير طبيعى شود در مطالعات قبلى (حاج

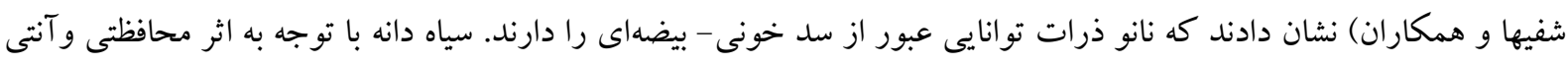
اكسيدانى مى تواند باعث بهبود اثرات سمى اكسيد تيتانيوم شود.

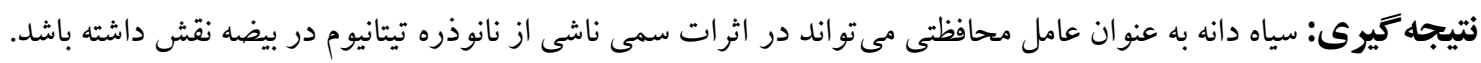
كليد وازه ها: نانوذره تيتانيوم ، سياه دانه ، بارامتر

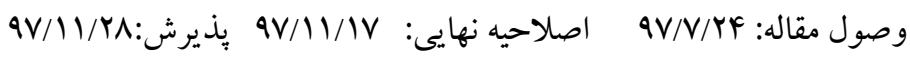

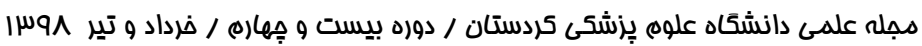


اثرات مفيد نانو ذرات با توجه به تحقيقات انجامشده نانوذره تيتانيوم مى تواند اثرات مضرى در بافت هاى مختلف در انسان با گسترش نانو تكنولوزى و مهندسى مواد، نانو ذرات مختلفى و موش ايجاد كند (·) (1). سياهدانه گياهى است از خانواده با خصوصيات جديد ساخته شده و علىرغم اينكه بتانسيل آلاله كه اثرات متعدد درمانى براى آن شناخته شده است اثرات سمى آنها در بسيارى از موارد ناشناخته است ولى (11). اين گياه در طب سنتى بسيارى از كشورها استفاده

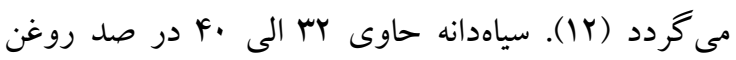

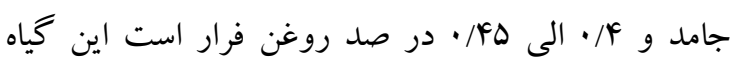
باعث كاهش ميزان توليد راديكالهاى آزاد اكسيثزن مىشود.

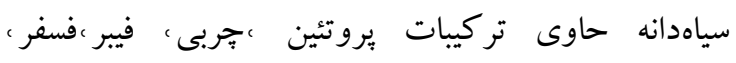
كلسيم ،نياسين ، تيامين ،ييرودوكسين و فوليكك اسيد است (r). تايمو كنين يكى از تركيب اصلى سياه دانه است كه داراى خاصيت آنتى اكسيدانى است (If).

\section{روش بروسى \\ حيوانها}

در اين مطالعه ·r سر موش بالغ نزاد (NMRI) سن A-4

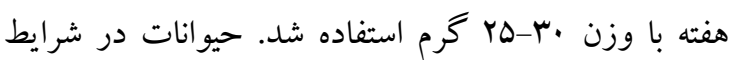
استاندارد آزمايشگاهى نگهدارى شدند (YI ساعت تاريكى و r إعت روشنايى •ه درصد رطوبت و دماى بr درجه

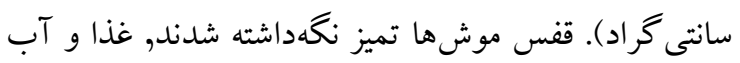

$$
\text { براى موش ها فر اهم شد. }
$$

\section{تيمار حيوانات}

موشهاى بالغ جهت انجام جفت گيرى ، Y موش ماده بالغ همر اه با يكك موش نر بالغ در يكك قفس قرار داده شدند. روز بعد بِ از مشاهده بِلاكك وازينال به عنوان روز اول حاملكَى در نظر گرفته شد. موشهاى حامله به صورت تصادفى به به

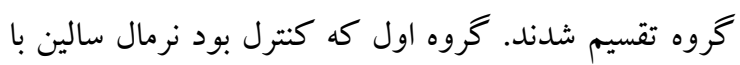
همان حجم تيتانيوم و سياه دانه و از طريق گاواز داده شد. كروه دوم به موشها ه mg/kg نانوذره اكسيد تيتانيوم

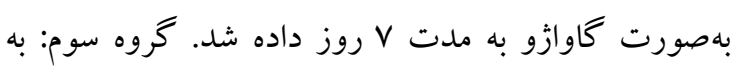
اين مواد كاربردهاى روزافزونى يافتهاند (1). نانو تكنولوزى عبارت است از دست كارى دقيق و كنترلشده ساختار اتمى يا مولكولى مواد در مقياس نانو بهمنظور تهيه ريز ذراتى با خصوصيات نوظهور و كاربردهاى خاص. بسيارى از مطالعات invivo و in vitro نشاندهنده اثرات منفى و مخرب نانو يارتيكلها بر سلولهاى زاياى جنس نر است (Y). ذرات نانو عبارتاند از ذرات اوليهاى كه حداقل يكى از ابعاد آنها كمتر از nm ·. 1 باشد (r). اكسيدهاى فلزى نانو ذرات در مقياس وسيعى هم در صنعت و هم در موارد خانگى كاربرد دارند (F). در بين نانو ذرات اكسيد روى و تيتانيوم جزو نانو ذرات مهم هستند كه در بسيارى از كشورها در مقياس صنعتى در حال استفاده مىباشند (ه). مطالعات زيادى نشاندهنده تجمع نانو ذرات در بافتهاى مختلف و همجنين تخريب سد خونى - بيضوى و سد خونى -مغزى است (9). در زمانهاى قديم از اكسيد تيتانيوم به علت داشتن ثبات ساختارى و قيمت يايين آن در افزودنىهاى غذايى

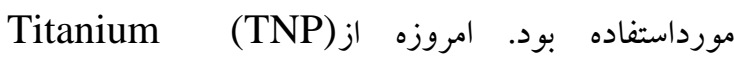
nanoparticle بهداشتى، مكملهاى غذايى و آبنبات، ساخت سراميك، تصفيه آب و فاضلاب و بسيارى موارد ديخر مانند شيشه ينجره، آسفالت و ديوارها استفاده مىشود (V). در سالهاى اخير بيشرفتهاى سريع فناورى نانو، سبب تحولات بزركى در زمينههاى محيطزيست، يزشكى، كشاورزى، صنعت و

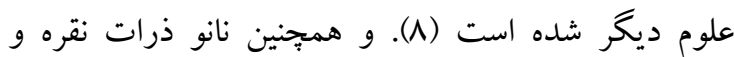
تيتانيوم دىاكسيد داراى اثر ضدميكروبى بر باكترىهاى Staphylococcus aureus PTCC 1431 و Listeria monocytogenes مىباشند (9). علاوه بر 
استفاده از لام نئوبار ودر زير ميكروسكوبٍ نورى شمارش

اسبرمها و مورفولوزى اسبرم مورد بررسى قرار گرفت.

تحليل آمارى

يس از كسب اطمينان از طبيعى بودن توزيع دادهها با استفاده

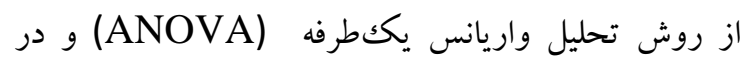
صورت معنىدار بودن از آزمون خیى دو استفاده شد.

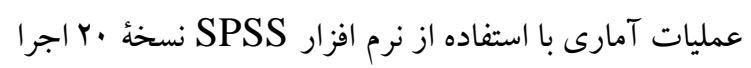

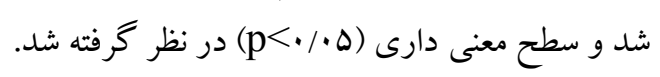

يافته ها

وزن اركانها

بررسى وزن بدن و بيضهها در جهار گروه انجام شام شد. وزن بدن و بيضه موشها در موشهاى گرووه كنترل و سياهدانه

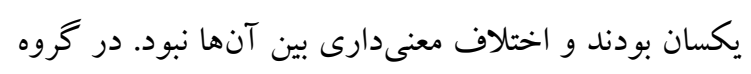
تيتانيوم وزن بدن و بيضه موشها كاهش داشته كه اين

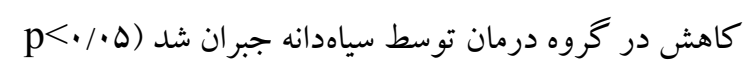

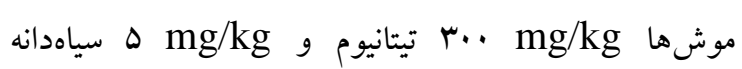
بهصورت گاواز به مدت V روز داده شد. در گروه جهارم كه گروه سياه دانه بود

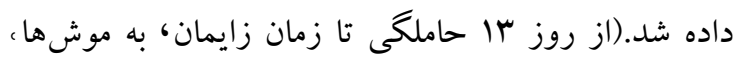

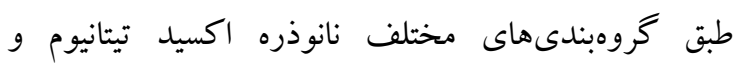

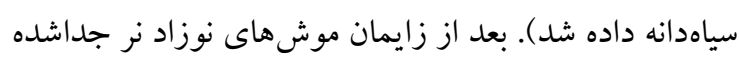

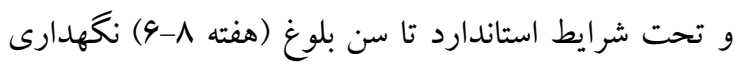
شدند. سبس موشها جهت انجام آزمايش با تكنيك جابجايى مهرههاى گردنى قربانى شدند.

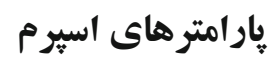

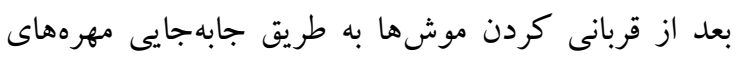

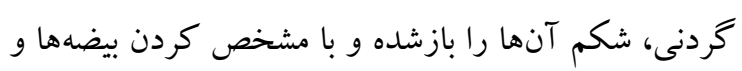

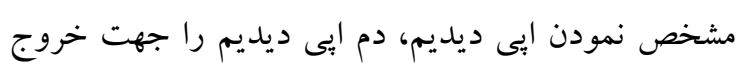

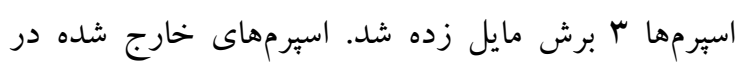

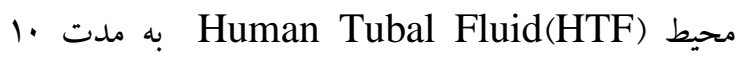

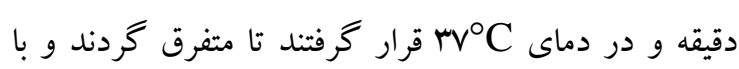

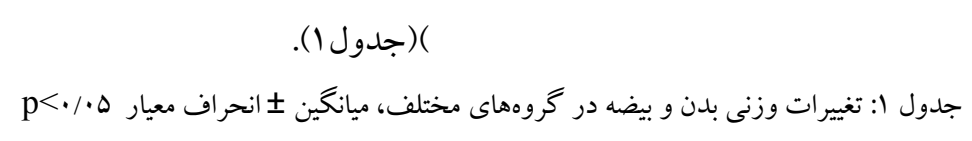

\section{(جدول (1).}

\begin{tabular}{|c|c|c|}
\hline كروه كنرل & $\begin{array}{l}\text { وزن بدن (كرم) } \\
r / \Delta \pm F / Y r\end{array}$ & 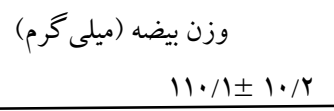 \\
\hline سيادانه & $r r / F \pm r / r$ & $111 / 9 \pm 9 / \Delta$ \\
\hline اكسيد تيتانيوم & $r N / Y \Psi \pm F / r$ & $Q 9 / \Delta \pm q / r$. \\
\hline سياه دانه+|كسيد تيتانيوم & $r \cdot \pm r / \Delta$ & $1.9 / \pi \pm 9 / 9$ \\
\hline
\end{tabular}

ديده نشد ولى كاهش تعداد اسبرمها در گروه تيتانيوم به

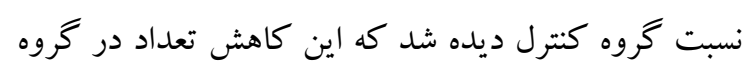
درمان توسط سياهدانه جبران شد (نمودار (1). از نظر مورفولوزى اسبرم، اسبرمهاى كروه كنترل و سياه دانه اختلاف معنى دارى با هم نداشتند ولى در گروه تيتانيوم

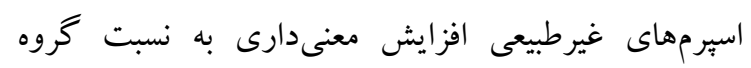

يار امترهاى سيمن در اين بررسى پيارامترهاى سيمن ازنظر تعداد اسيرم و ورائ

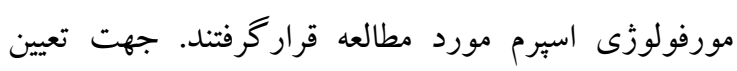

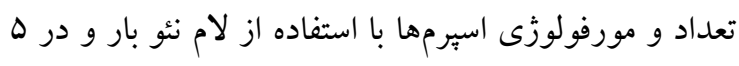
ميدان مختلف مورد بررسى قرار گرفت. در گروه سياه دانه

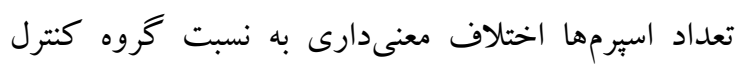




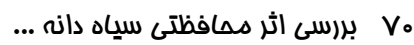

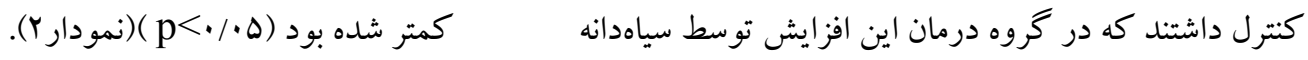

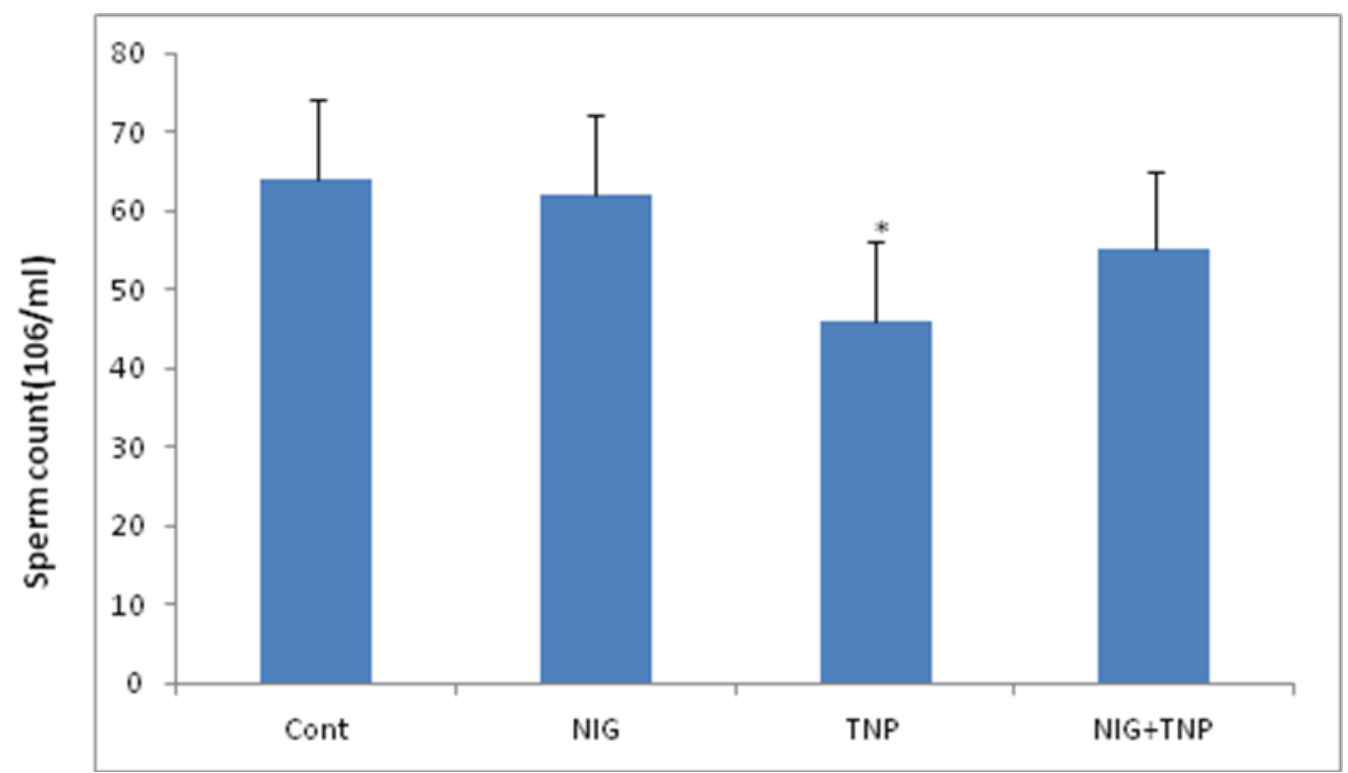

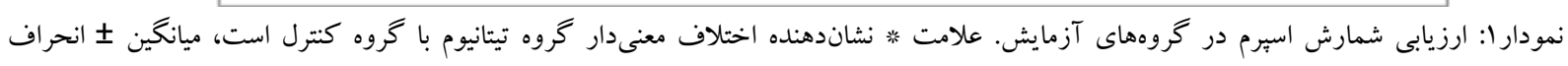
$P^{*}<\cdot / \cdot 1.11$ معيار

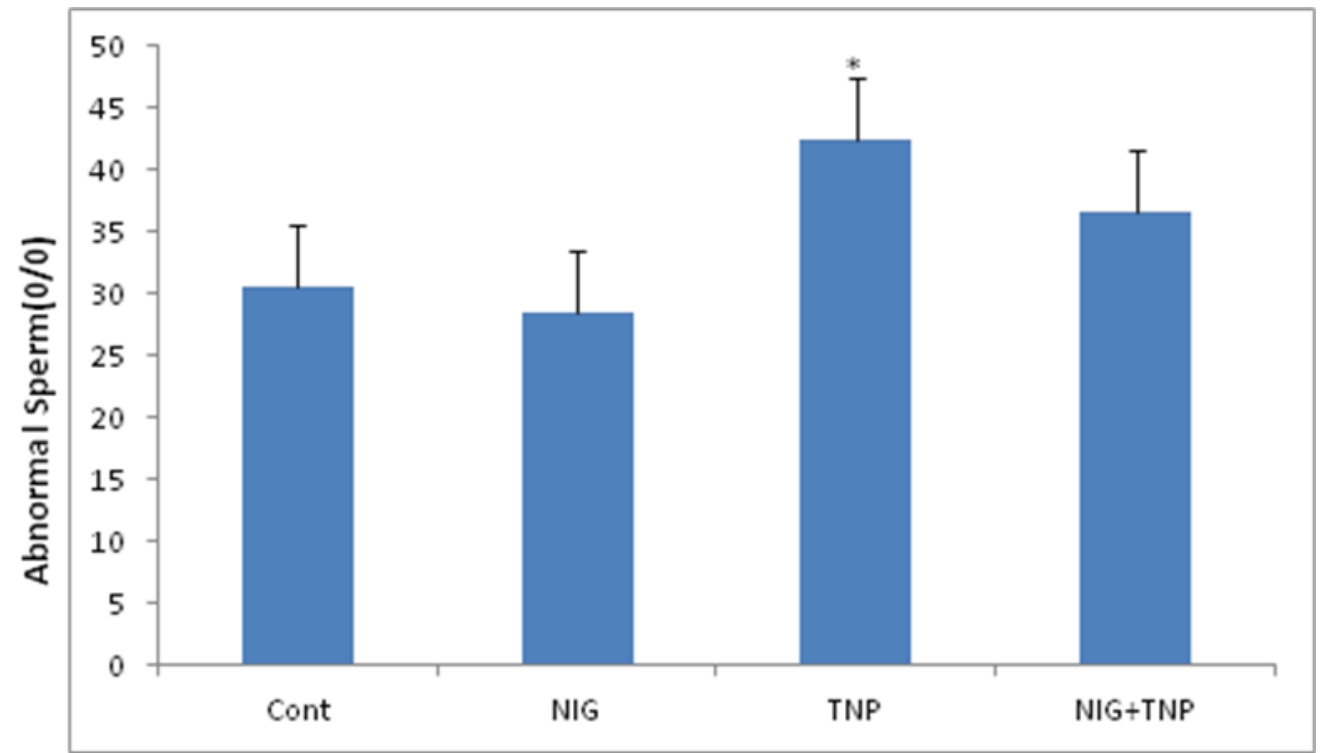

نمودار ז: ارزيابى مورفولوزى اسبرم در گروه كنترل و گروهاى ديخر.علامت * نشاندهنده اختلاف معنىدار گروه تيتانيوم با گروه كنترل است، ميانگين

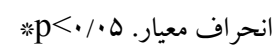


سيليكا، كربن سياه، آلومينيوم و موليبيديوم ترى اكسيد داراى اثرات سوء بر فرآيند اسِرماتوزنز هستند و باعث تغييرات هيستوياتولوزى در بافت بيضه مىشوند و همجنين سلولهاى ليديگك و سلولهاى بنيادى اسبرماتو گونى را تحت تأثير قرار مىدهند (Y)). در اين تحقيق همجنين مشخص شد كه سياهدانه بهطور مؤثرى باعث افزايش شمارش اسبرم و كاهش اسبرمهاى غيرطبيى مىشود كه

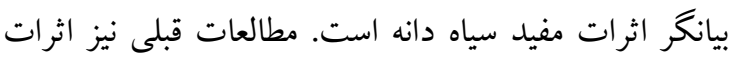

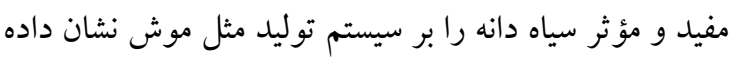
اند (YY). هالى و همكاران در سال II Y مشخص كردند

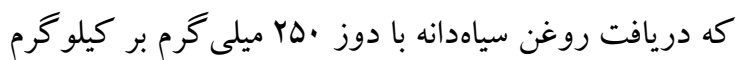

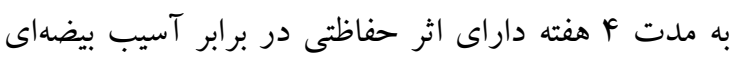

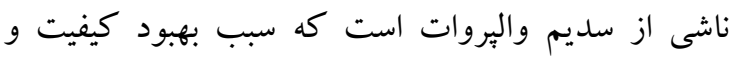
كميت مايع منى و كاهش براكسيداسيون ليييدى در بيضه

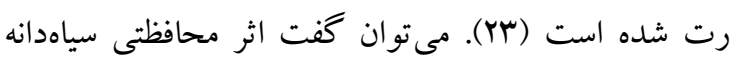

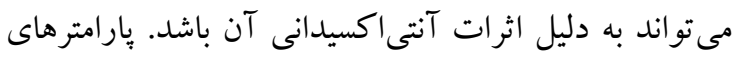
اسبرم إيديديم توسط سياه دانه تغييرات مثبتى داشته است. در تحقيقات قبلى ثابت شده است كه سياه دانه باعث بهبود حركت اسيرم و افزايش حيات اسبرم مىشود (YF). احمد الساعدى وهمكاران نشان دادند كه استفاده از سياهدانه منجر به بهبود اسيرماتوزنز و همجنين باعث افزايش اندازه و ضخامت ديواره لولههاى اسبرمساز و تعداد سلولهاى

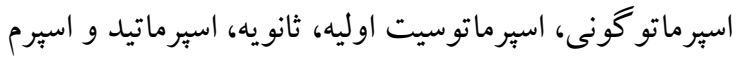
ها در لومن لوله هاى اسبرم ساز شده است (YD).

\section{نتيجه كيرى}

نانو ذره تيتانيوم در دوران جنينى مىتواند اثر مخرب بر سيستم تناسلى داشته باشد كه سياهدانه به عنوان عامل محافظتى مى تواند در كاهش اثرات منفى اين نانوذره نقش

داشته باشد.

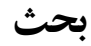

در سالهاى اخير در بسيارى از مطالعات اثرات سمى نانو ذرات موردبررسى قرارگرفته است اما تا به حال در جهت كاهش اثرات سمى آن يُوهشهاى كمترى صورت گرفته است. در اين تحقيق اثر محافظتى سياهدانه بر اثرات مخرب نانوذره اكسيد تيتانيوم بر يارامترهاى اسيرم (شمارش اسيرم و مورفولوزى اسيرم) مورد مطالعه قرار گرفته است. نتايج اين تحقيق نشان داد كه نانوذره اكسيد تيتانيوم مىتواند باعث كاهش شمارش اسيرم و افزايش اسيرمهاى غيرطبيعى شود كه اين نتايج شبيه مطالعهاى است كه در آن حاج شفيع و

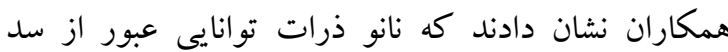
خونى - بيضهاى را دارند و تعدادى از آنها اثرات مخرب و

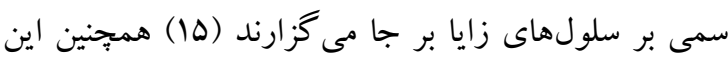

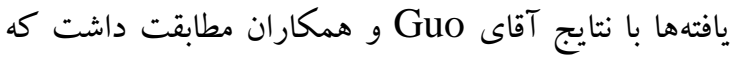
نشان دادند TNP در رت باعث كاهش شمارش اسبرم و حركات اسبرم مىشود (19). حركات اسبرم مى بونواند

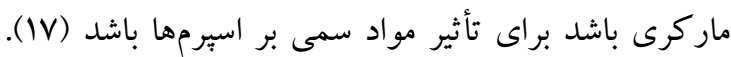

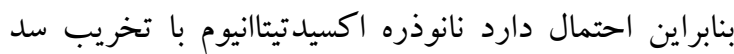
خونى -بيضهاى وارد لوله منى ساز شده و مستقيماً سلولهاى زايا يا سرتولى را تحت تأثير قرار داده باشد. همكارانش در سال 9..r با مطالعه بر روى نانو ذرات مغناطيسى به روش تزريق داخل صفاقى نشان دادند كه اين

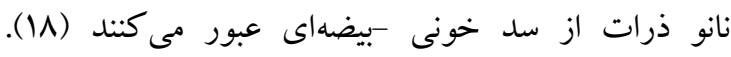

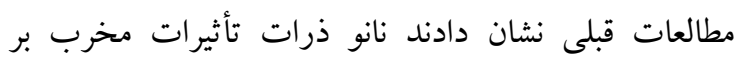
سلولهاى زاياى جنس نر دارند. - GromadzkaOstrowsk و همكاران نشان دادند كه نانوذره نقره اثر مخرب بر سلولهاى زايا دارد و باعث كاهش كيفيت اسبرم مى گردد (19). Yoshida و همكاران نشان دادند كه نانو

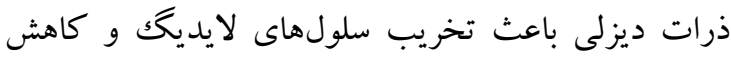

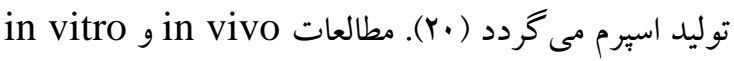
مشخص كردهاند كه نانو ذراتى مانند اكسيد تيتانيوم، طلا،

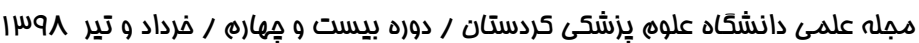




$$
\text { تأمينشده است و كه بدينوسيله از اين معاونت تشكر }
$$

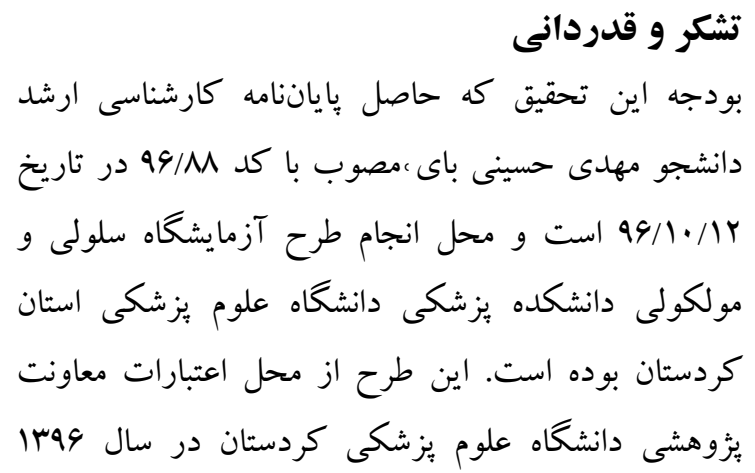

\section{Reference}

1. Seaton A. Nanotechnology and the occupational physician. Occup Med 2006;56:312- 6.

2. Braydich LK, Lucas B, Schrand A, Murdock RC, Lee T, Schlager JJ, et al. Silver nanoparticles disrupt GDNF/Fyn kinase signaling in spermatogonial stem cells. Toxicol Sci 2010;116:577-89.

3. Donaldson K, Tran L, Jimenez LA, Duffin R, Newby DE, Mills N, et al. Combustion-derived nanoparticles: A review of their toxicology following inhalation exposure. Part Fibre Toxicol 2005;2:10.

4. Chow JC. Nanoparticles and environment. J Air Waste Manag Assoc 2005;55:706-7.

5. Heinlaan M, Ivask A, Blinova I, Dubourguier HC, Kahru A. Toxicity of nanosized and bulk $\mathrm{ZnO}, \mathrm{CuO}$ and $\mathrm{TiO} 2$ to bacteria Vibrio fischeri and crustaceans Daphnia magna and Thamnocephalus platyurus. Chemosphere 2008;71:1308-16.

6. Borm PJ, Kreyling W. Toxicological hazards of inhaled nanoparticles potential implications for drug delivery. J NanosciNanotechnol 2004;4:521-31.

7. Lee J, Mahendra S, Alvarez PJ. Nanomaterials in the construction industry: a review of their applications and environmental health and safety consider-ations. ACS Nano 2010;4:3580-90.

8. Gogos A, Knauer K, Bucheli TD. Nanomaterials in plant protection and fertilization: current state, foreseen applications, and research priorities. J Agric Food Chem 2012;60:9781-92.

9. Mohammad N, Iman P, Rasoul K, Elham E. Antimicrobial effect of zinc oxide and silver nitrate nanoparticles against S. aureus, A. baumannii and P. aeruginosa. JBCP 2019;7:17-30.

10. Liu H, Ma L, Zhao J, Liu J, Yan J, J Ruan, et al. Biochemical toxicity of nano-anatase TiO2 particles in mice. Biol Trace Elem Res 2009;129:170-80.

11. Amin B, Hosseinzadeh H. Black Cumin (Nigella sativa) and its active constituent, thymoquinone: an overview on the analgesic and anti-inflammatory effects. Planta Med 2016;82:8-16.

12. Weinstein RA. Controlling antimicrobial resistance in hospitals: infection control and use of antibiotics. Emerg Infect Dis 2001;7:188-92.

13. Kanter M, Coskun O, Korkmaz A, Oter S. Effects of Nigella sativa on oxidative stress and beta-cell damage in streptozotocin-induced diabetic rats. Anat Rec ADiscov Mol Cell Evol Biol 2004;279:685-91.

14. Mosaddegh $\mathrm{M}$, Naghibi F, editors. Iranian traditional medicine, past and present. International Seminar on "Integration of Traditional Medicine (Complementary/Alternative) and Modern Medicine"2002 Oct. 12-15, Cairo, Egypt, 2002. 2-20 
عرفان دانشى V V

15. Hajshafiha M, Ghareaghaji R, Salemi S, Sadegh-Asadi N, SadeghiBazargani H. Association of body mass index with some fertility markers among male partners of infertile couples. Int $\mathbf{J}$ Gen Med 2013;6:447-5.

16. Guo LL, Liu XH, Qin DX, Gao L, Zhang HM, Liu JY, et al. Effects of nanosized titanium dioxide on the reproductive system of male mice. Zhonghua Nan Ke Xue 2009; 15:517-22.

17. El-Demerdash FM, Yousef MI, Kedwany FS, Baghdadi HB. Role of $\alpha$-tocopherol and $\beta$ carotene in ameliorating the fenvalerate-induced changes in oxidative stress, hemato-biochemical parameters, and semen quality of male rats. J Environ Sci Health B 2004;39:443-59.

18. Kim JS, Yoon TJ, Yu KN, Kim BG, Park SJ, Kim HW, et al. Toxicity and tissue distribution of magnetic nanoparticles in mice. Toxicol Sci 2006;89:338-47.

19. Gromadzka-Ostrowskaa J, Dziendzikowskaa K, Lankoffb A, Dobrzyńska M, Instanes C, Brunborg G, et al. Silver nanoparticles effects on epididymal spermin rats. Toxicol Lett 2012;214:251-8.

20. Yoshida S, Sagai M, Oshio S, Umeda T, Ihara T, Sugamata M, et al. Exposure to diesel exhaust affects the male reproductive system of mice. Int J Androl 1999;22:307-15.

21. Talebi AR, Khorsandi L, Moridian M. The effect of zinc oxide nanoparticles on mouse spermatogenesis. J Assist Reprod Genet 2013;30:1203-9.

22. Ali $\mathrm{BH}$ and Blundeh G. Pharmacological and toxicological properties of Nigella sativa. Pytother Res 2003;17:299-305.

23. Hooley RP, Paterson M, Brown P, Kerr K, Saunders PTK. Intratesticular injection of adenoviral constructs results in Sertolicellspecific gene expression and disruption of the seminiferous epithelium. Reproduction 2009;137:361-70.

24. Ghlissi Z, Hamden K, Saoudi M, Sahnoun Z, Zeghal KM, El Feki A, et al. Effect of Nigella sativa seeds on reproductive system of male diabetic rats. Afr J Pharm Pharmacol 2012;6:144450.

25. Ahmad A, Husain A, Mujeeb M, Khan SA, Najmi AK, Siddique NA, et al. A review on therapeutic potential of Nigella sativa: A miracle herb. Asian Pac J Trop Biomed 2013;3:337-52. 